\title{
Investigating Factors Affecting Capital Structure of Equitized State-Owned Enterprises in Ho Chi Minh City
}

\author{
TRAN THI THUY LINH \\ University of Economics HCMC - linhtcdn@ ueh.edu.vn
}

\section{ARTICLE INFO ABSTRACT}

Article history:

Received:

Aug. 272014

Received in revised form:

Jan. 302015

Accepted:

Sep. 152015

Keywords:

Capital structure, state ownership, financial leverage, equitized SOEs.
Using panel data along with the application of Pooled OLS, FEM, and REM estimates, this study conducts an investigation into the effects of a series of factors, namely state ownership, size, tangible assets, growth, return on assets (ROA), effective tax rate, and liquidity, on capital structure of 165 HCMC-based equitized state-owned enterprises (SOEs), categorized into three groups over the 2008-2012 period. As suggested by the findings, tangible assets, ROA, and liquidity are negatively related to leverage ratio and short-term debt ratio for the three groups of enterprises. In terms of firm size, there exists a positive correlation with leverage ratio and short-term debt ratio for Group 1 and 2 but a negative correlation with short-term debt ratio for the case of Group 3. 


\section{Introduction}

As one of the most common measures during the process of restructuring state-owned enterprises (hereafter referred to as SOEs), equitization is believed to promote high economic efficiency, foster the diversification of ownership, thereby changing capital structure as well as uplifting capital efficiency among SOEs. Decision No. 929/QD-TTg issued by the Government on July 17, 2012, approved the scheme on restructuring SOEs with a focus on economic groups and state-owned corporations between 2011 and 2015. As planned by 2015, there are 531 enterprises equitized, 25 merged/acquired, 10 sold, and 16 dissolved and/or bankrupted. The reform progress, however, has been incredibly slow: in 2012 the country witnessed the equitization of 13 enterprises (about $14 \%$ of the number planned), whereas the figure for the first seven months of 2013 was merely 16. Additionally, SOEs' indebtedness is now placing them on a state of alert.

Currently, many theoretical and empirical studies set out to examine the relation between ownership structure and corporate financing decisions, including Dewenter and Malatesta (2001), Jong et al. (2008), Firth et al. (2009), Li et al. (2009), and Liu et al. (2011). Thus, to assess the restructuring of financial sources of equitized SOEs, an investigation into effects of a few factors on their capital structure proves necessary. This study is grounded on three guiding questions: (i) Does state ownership affect the capital structure of HCMC-based equitized SOEs? (ii) Which specific factors have impact on their capital structure? and (iii) Does there exist any difference in the level of effects of these factors on the capital structure of three groups of equitized SOEs?

\section{Theoretical bases and empirical studies}

\subsection{Theoretical bases}

According to Modigliani and Miller (1958), financing decisions have no impact on capital structure in perfect capital markets. Firm value is independent of the capital structure, determined by real assets rather than the securities it issues.

Trade-off theory (Scott, 1977) assumes that firms need to trade-off debt and equity to maximize tax shield benefits and costs of debt, and the theory managed to target the difference in capital structure among industries. Firms with higher profits are supposed to decide on the capital structure with a high debt ratio. 
Pecking order theory (Myers \& Majluf, 1984, as extended by Lucas \& McDonald, 1990) verifies that firms use internal financing when available and prefer debt to equity when external financing is needed. Ordinarily, new equity issues are the ultimate solution in case of little borrowing capability and the risk of financial distress. Hence, firms prioritize internal financing, mainly retained earnings, followed by debt, and subsequently, newly issued equity.

The agency theory (Fama \& Miller, 1972, as extended by Jensen \& Meckling, 1976 and Jensen, 1986) discusses effects of agency costs on capital structure in the context of different conflicts of interest between stockholders and managers and between stockholders and creditors during the use of either debt or equity. The optimal capital structure is determined by the agency costs, resulting from the trade-off between benefits (ownership) and costs (stockholders' risk) in debt financing.

\subsection{Empirical research}

The findings attained by Mackie-Mason (1990) came in line with what has been suggested by the trade-off theory as firms, during tax payment, have preferential access to debt in order to enlarge the tax shield. Thus, effective tax rate is positively related to financial leverage.

Dewenter and Pettway (2001) noted that it is more likely for state-owned firms to employ financial leverage than private ones and that a positive correlation exists between state ownership and financial leverage. Meanwhile, Jong et al. (2008), Bas et al. (2009), and Chen (2004), who examined the case of China, and Wald (1999), investigating developing nations, explored a negative relation between financial leverage and corporate growth rate; either firms showing growth potential commonly go for equity financing or those with high returns reflect a downward trend in using external financing.

Jong et al. (2008) when examining factors exerting effects on firms' capital structure detected tangible fixed assets and firm size, positively related to leverage, while risk, profitability, growth, liquidity, and effective tax rate are negatively related to leverage, consistent with the capital structure theory. As for Bas et al (2009), Chen (2004), Rajan and Zingales (1995), and Ozkan (2002), a positive correlation between leverage and tangible fixed assets can be found among developing countries, whereas Deesomsak et al. (2004) realized the case with empirical evidence from Asia Pacific region. 
Similarly, Li et al. (2009), Firth et al. (2009), and Liu et al. (2011) investigated the nexus between ownership structure and capital structure in China. Their empirical findings suggested that state ownership is crucial to capital structure decisions made by Chinese firms, and it has positive and negative relations with long- and short-run leverage respectively. Financial leverage of SOEs, in addition, was found to be higher than that of non-SOEs.

Okuda and Lai (2010) examined the determinants of fundraising structure for the case of Vietnamese listed SOEs. The study accentuated the important role of collateral in long-term loans requested by firms, be they qualified listed enterprises or not.

Nadeem and Wang (2011) empirically studied the impact of liquidity on financial leverage, figuring out a negative relation between the two factors.

In Vietnam Nguyen and Ramachandran (2006), in examining the relation between state ownership and capital structure of SMEs observed that SOEs use leverage more customarily than non-SOEs since the higher the state ownership, the more easily these firms access loans.

\section{Methodology}

\subsection{Research data}

The data sets are collected from HCMC Department of Finance and HCMC Branch of Department for Entrepreneurial Finance, pursuant to Circular No. 220/2013/TT-BTC dated December 31, 2013. The preliminary research sample comprises 226 firms affiliated to 11 corporations and seven groups of single-member LLC over the 20082012 period. Since a few of them have presented insufficient or no available financial statements or are not categorized as state owned, there remain a total of 165 firms to be surveyed after elimination. Data of 2013 are not available due to the secondary statistics reported by HCMC Branch of Department for Entrepreneurial Finance. To perform data analysis of each firm, Microsoft Excel and Eview 6.0 are then employed.

Following the methods applied by Jong et al. (2008) and Liu et al. (2011), the study uses panel data based on the financial statements provided by representatives of equitized SOEs. To perceive the difference in capital structure under the influence of state ownership, as suggested by Decision No. 15/2006/QD-BTC, these firms can be classified into three of the following groups: 
- Equitized SOEs with state shareholding of 51\% or more (51 enterprises)

- Equitized SOEs with state shareholding of 30-50\% (46 enterprises)

- Equitized SOEs with state shareholding of less than 30\% (68 enterprises)

\subsection{Variable description and hypotheses}

Analyses of the variables used in the study are based on those suggested by Jong et al (2008), and Liu et al. (2011).

\section{Dependent variables}

- Leverage ratio (LEV): ratio of total liabilities to total assets; LEV is used to determine obligation of firm's owner to creditors in capital structure.

- Short-term debt ratio (STDR): ratio of total short-term debt to total assets, showing the influence of firms' liquidity and investment decisions when their agents wish to control the risk of business performance.

- Long-term debt ratio (LTDR): ratio of total long-term debt to total assets. This reflects the level of firms' using leverage and becomes higher when firms grow stronger, especially for those with a high rate of state ownership.

\section{Independent variables}

- State ownership: The sample includes equitized SOEs categorized into the three groups as detained in section 3.1., so the variable becomes distinct in the sampling and research data.

- Tangible assets (TANG): total tangible fixed assets as a ratio to total assets. According to the trade-off theory (Scott, 1977) and as discussed by Jong et al. (2008), firms with large proportions of tangible assets use more debt than those with great intangible assets because creditors in their lendings would require certain collateral.

- Firm size (SIZE): log of total assets, which estimates the investment-financing relationship. Liu et al. (2011) noted that large-scaled firms often use long-term debt, whereas short-term debt is favored by small-scaled ones. These characteristics imply a positive relation between firm size and its financial leverage.

- Growth (GROWTH): measured by the increase in income. Regarding discussions from Scott (1977), Myers and Majluf (1984), and Jong et al. (2008), when firms show 
high growth potential, priority will be given to the use of internal financing sources, thus implying growth negatively related to leverage.

- Return on assets (ROA): ratio of pre-tax profits to total assets. Myers and Majluf (1984), Wald (1999), and Jong et al. (2008) agreed that firms with high returns are less likely to use external financing sources.

- Effective tax rate (TAX): ratio of total tax paid by the firm to total assets. Modigliani and Miller (1963) proposed that firms that are taxed with a higher marginal tax rate are likely to use more debt to benefit from the tax shield. Jong et al. (2008) concluded that a positive relation is held between effective tax rate and financial leverage.

- Liquidity (LIQUID): short-term assets as a ratio to aggregate short-term liabilities. Scott's (1977) trade-off theory implicated high liquidity as a cause of more corporate loans, whereas according to Myers and Majluf (1984), firms may use their liquid assets available in large amount to finance their own investment projects.

Research hypotheses

Prior theories and empirical findings allow the following hypotheses to be formulated:

H1: Tangible assets positively relates to leverage.

H2: Size positively relates to leverage.

H3: Growth positively relates to leverage.

H4: Return on assets negatively relates to leverage.

H5: Effective tax rate positively relates to leverage.

H6: Liquidity negatively relates to leverage.

\subsection{Research model}

Since state ownership falls into the three groups mentioned earlier, the research model comprises the following equations used to test each group of enterprises:

- Equation 1:

$\mathrm{LEV}_{\mathrm{i}, \mathrm{t}}=\beta_{0}+\beta_{1} . \mathrm{TANG}_{\mathrm{i}, \mathrm{t}}+\beta_{2} . \mathrm{SIZE}_{\mathrm{i}, \mathrm{t}}+\beta_{3} . \mathrm{GROWTH}_{\mathrm{i}, \mathrm{t}}+\beta_{4} . \mathrm{ROA}_{\mathrm{i}, \mathrm{t}}+\beta_{5} . \mathrm{TAX}_{\mathrm{i}, \mathrm{t}}$ $++\beta_{6} \cdot$ LIQUID $_{\mathrm{i}, \mathrm{t}}+\varepsilon_{\mathrm{i}}$

- Equation 2: 
$\operatorname{STDR}_{\mathrm{i}, \mathrm{t}}=\beta_{0}+\beta_{1}$. TANG $_{\mathrm{i}, \mathrm{t}}+\beta_{2} . \mathrm{SIZE}_{\mathrm{i}, \mathrm{t}}+\beta_{3} . \mathrm{GROWTH}_{\mathrm{i}, \mathrm{t}}+\beta_{4} \cdot \mathrm{ROA}_{\mathrm{i}, \mathrm{t}}+\beta_{5} . \mathrm{TAX}_{\mathrm{i},}$ ${ }_{\mathrm{t}}+\beta_{6} \cdot$ LIQUID $_{\mathrm{i}, \mathrm{t}}+\varepsilon_{\mathrm{i}}$

- Equation 3

$\operatorname{LTDR}_{\mathrm{i}, \mathrm{t}}=\beta_{0}+\beta_{1} . \mathrm{TANG}_{\mathrm{i}, \mathrm{t}}+\beta_{2} . \mathrm{SIZE}_{\mathrm{i}, \mathrm{t}}+\beta_{3} . \mathrm{GROWTH}_{\mathrm{i}, \mathrm{t}}+\beta_{4} . \mathrm{ROA}_{\mathrm{i}, \mathrm{t}}+\beta_{5} . \mathrm{TAX}_{\mathrm{i}}$, ${ }_{\mathrm{t}}+\beta_{6} \cdot \mathrm{LIQID}_{\mathrm{i}, \mathrm{t}}+\varepsilon_{\mathrm{i}}$

where:

$\mathrm{LEV}_{\mathrm{i}, \mathrm{t}}$ : leverage ratio, ratio of total liabilities to total assets of firm $i$ in year $t$;

$\mathrm{STDR}_{\mathrm{i}, \mathrm{t}}$ : short-term debt ratio, total short-term debt as a ratio to total assets of firm $i$ in year $t$;

LTDR $_{\mathrm{i}, \mathrm{t}}$ : long-term debt ratio, total short-term debt as a ratio to total assets of firm $i$ in year $t$;

$\mathrm{TANG}_{\mathrm{i}, \mathrm{t}}$ : tangible assets, total tangible fixed assets as a ratio to total assets of firm $i$ in year $t$;

SIZE $_{\mathrm{i}, t}$ : size of firm $i$ in year $t$;

GROWTH $_{\mathrm{i}, \mathrm{t}}$ : growth of firm $i$ in year $t$;

$\mathrm{ROA}_{\mathrm{i}, \mathrm{t}}$ : return on assets of firm $i$ in year $t$;

$\mathrm{TAX}_{\mathrm{i}, \mathrm{t}}$ : effective tax rate of firm $i$ in year $t$;

LIQUID $_{\mathrm{i}, \mathrm{t}}$ : liquidity of firm $i$ in year $t$

In addition to descriptive statistics and correlation analysis, Pooled OLS regression is performed to determine the variables with statistical significance. The author also conducts Durbin-Watson, White, Breusch-Pagan-Godfrey tests for the adequacy of the Pooled OLS estimator. Furthermore, FEM and REM for panel data are applied, and Hausman test, used to decide on their suitability.

\section{Evaluation of capital structure decisions}

\subsection{The current state of capital structure decisions of equitized SOEs in HCMC}

Statistics released by HCMC Branch of Department for Entrepreneurial Finance shows different kinds of average debt ratio among the enterprises in the three groups: 


\section{Table 1}

Average debt ratio of equitized SOEs between 2008 and 2012

\begin{tabular}{lcccc}
\hline $\begin{array}{l}\text { Group of enterprises categorized } \\
\text { by state ownership }\end{array}$ & $\begin{array}{c}\text { Total } \\
\text { liabilities/total } \\
\text { assets } \\
(\%)\end{array}$ & $\begin{array}{c}\text { Total } \\
\text { long-term } \\
\text { debt/total } \\
\text { assets } \\
(\%)\end{array}$ & $\begin{array}{c}\text { Total short- } \\
\text { term } \\
\text { debt/total } \\
\text { assets } \\
(\%)\end{array}$ & $\begin{array}{c}\text { Income after } \\
\text { tax/equity } \\
(\%)\end{array}$ \\
\hline $\begin{array}{l}\text { Equitized SOEs with state } \\
\text { shareholding of 51\% or more }\end{array}$ & 51.21 & 6.68 & 44.52 & 14.65 \\
$\begin{array}{l}\text { Equitized SOEs with state } \\
\text { shareholding of 30-50\% }\end{array}$ & 48.66 & 6.08 & 42.58 & 14.08 \\
$\begin{array}{l}\text { Equitized SOEs with state } \\
\text { shareholding of less than 30\% }\end{array}$ & 49.1 & 9.45 & 39.62 & 10.79 \\
$\begin{array}{l}\text { Average calculated for three } \\
\text { groups (\%) }\end{array}$ & 49.66 & 7.4 & 42.24 & 13.17 \\
\hline
\end{tabular}

Source: compiled from HCMC Branch of Department for Entrepreneurial Finance statistics

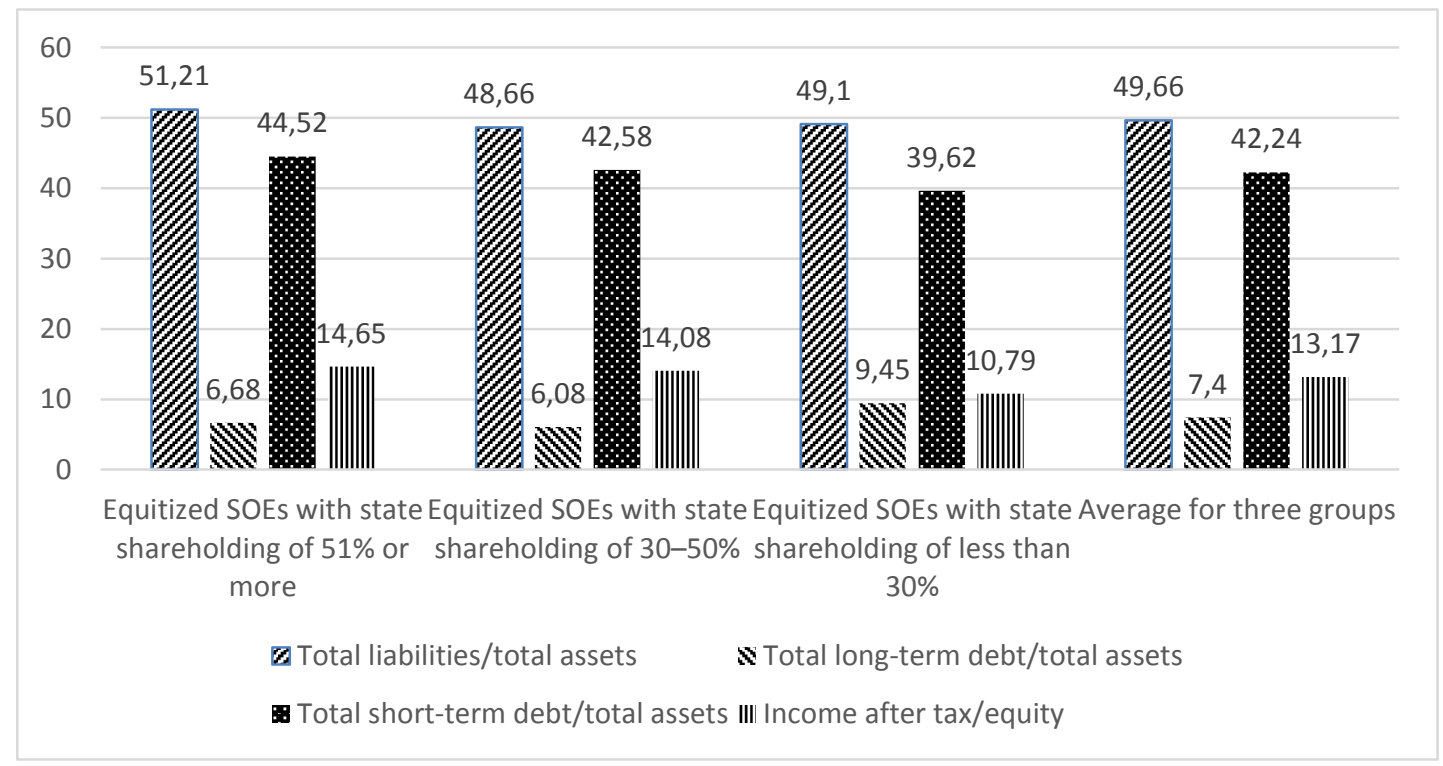

Figure 1. Financial ratios of equitized SOEs between 2011 and 2012

Source: compiled from HCMC Branch of Department for Entrepreneurial Finance statistics 
Table 1 shows that average leverage ratio for the three groups of enterprises is approximately $49.66 \%$, similar to the average of $47 \%$ as were found by Okuda and Lai (2010); thus, equity financing and debt financing are roughly equivalent. Since shortterm debt ratios for Groups 1, 2, and 3 are pretty high, reaching 44.52\%, 42.58\%, and $39.62 \%$ respectively, implying that debt financing mostly comes from the short-term one.

Regarding long-term debt ratio, the average for the three groups is 7.4\%; particularly, Group 3 reveals the highest ratio of $9.45 \%$. Average return on equity reaches $13.17 \%$ for the three groups, among which Group 3 reflects a lower rate of $10.79 \%$, as compared to Group 1 and 2. Rates of return on assets for Groups 1, 2, and 3 are 6.48\%, 7.14\%, and $5.64 \%$ respectively, showing the effect of state ownership on capital structure and performance of the three groups of enterprises.

\subsection{Different analyses of variables}

\subsubsection{Statistical description}

On the basis of 165 equitized SOEs an analysis is performed of a total of 825 observations (255, 230, and 340 observations for Groups 1, 2, and 3 respectively). The results of descriptive statistics are presented as follows:

\section{Table 2}

Statistical description of variables for Group 1 firms

\begin{tabular}{ccccccccccc}
\hline & LEV & STDR & LTDR & TANG & SIZE & GROWTH & ROA & TAX & LIQUID \\
\hline Mean & 0.5121 & 0.4452 & 0.0668 & 0.1901 & 4.8945 & 0.1843 & 0.0648 & 0.1084 & 2.4199 \\
Median & 0.5557 & 0.4140 & 0.0081 & 0.1355 & 4.9159 & 0.0944 & 0.0574 & 0.0697 & 1.5397 \\
Maximum & 0.9831 & 0.9155 & 0.5266 & 0.7099 & 5.9073 & 4.7820 & 0.3702 & 0.8932 & 24.9557 \\
Minimum & 0.0612 & 0.0247 & 0.0000 & 0.0008 & 3.5181 & -0.7101 & -0.3920 & 0.0000 & 0.3372 \\
Std. dev. & 0.2461 & 0.2565 & 0.1189 & 0.1870 & 0.5128 & 0.6908 & 0.0714 & 0.1338 & 2.3607 \\
Skewness & -0.1553 & 0.1439 & 2.2665 & 0.9069 & -0.1557 & 4.1468 & -0.4620 & 3.1556 & 4.7896 \\
Kurtosis & 1.8182 & 1.6076 & 7.4475 & 2.8615 & 2.1841 & 24.5083 & 10.9706 & 15.9698 & 37.9409 \\
Number of obs. & 255 & 255 & 255 & 255 & 255 & 255 & 255 & 255 & 255 \\
\hline
\end{tabular}

Source: author's compilation using Eviews 8.0 
Table 2 shows that the mean of LEV is $51.2 \%$, whereas the figures for STDR and LTDR are $44.5 \%$ and $6.68 \%$ respectively. Since long-term debt reveals a very low ratio, the enterprises with state shareholding of $51 \%$ or more primarily use short-term debt and equity financing, which is similar to Liu et al.'s (2011) findings. Furthermore, an extremely low value of ROA displays a loss, which can be traced back to the year 2010, as typically suffered by Saigon Shipping JSC, Saigon Mechanical and Casting JSC, etc.

\section{Table 3}

Statistical description of variables for Group 2 firms

\begin{tabular}{lccccccccc}
\hline & LEV & STDR & LTDR & TANG & SIZE & GROWTH & ROA & TAX & LIQUID \\
\hline Mean & 0.4866 & 0.4258 & 0.0608 & 0.1754 & 4.6001 & 0.1575 & 0.0714 & 0.1034 & 3.9036 \\
Median & 0.4988 & 0.4055 & 0.0085 & 0.1050 & 4.6114 & 0.0361 & 0.0531 & 0.0630 & 1.8701 \\
Maximum & 0.9922 & 0.9555 & 0.8731 & 0.8908 & 5.6240 & 4.7820 & 0.7887 & 0.9176 & 27.7273 \\
Minimum & 0.0158 & 0.0093 & 0.0000 & 0.0000 & 3.3103 & -0.8197 & -0.7702 & -0.0012 & 0.3372 \\
Std. dev. & 0.2740 & 0.2820 & 0.1289 & 0.1908 & 0.5041 & 0.7167 & 0.1229 & 0.1334 & 5.6660 \\
Skewness & -0.0722 & 0.2188 & 3.5336 & 1.5466 & -0.0450 & 3.7639 & -0.1932 & 3.0784 & 3.0468 \\
Kurtosis & 1.8022 & 1.7643 & 17.6349 & 5.2379 & 2.6461 & 21.4741 & 19.4800 & 15.5048 & 11.8493 \\
Number of obs. & 230 & 230 & 230 & 230 & 230 & 230 & 230 & 230 & 230 \\
\hline
\end{tabular}

Source: author's compilation using Eviews 8.0

The mean of LEV, as reported by Table 3, is $48.66 \%$, whereas the figures for STDR and LTDR are $42.58 \%$ and $6.08 \%$ respectively besides the lowest ratio of zero. Similarly, short-term debt and equity financing sources are mainly favored by equitized SOEs with state shareholding of 30-50\%. ROA of Group 2 SOEs shows the mean, maximum, and minimum values of $7.14 \%, 78.87 \%$, and $-77.02 \%$ respectively with a loss since 2010, suffered by Thu Duc Automobile Mechanical JSC, Printing Mechanical JSC, etc.

\section{Table 4}

Statistical description of variables for Group 3 firms

\begin{tabular}{cccccccccc}
\hline & LEV & STDR & LTDR & TANG & SIZE & GROWTH & ROA & TAX & LIQUID \\
\hline Mean & 0.4910 & 0.3962 & 0.0945 & 0.1915 & 5.0555 & 0.2263 & 0.0564 & 0.0527 & 3.2654 \\
Median & 0.5011 & 0.3669 & 0.0164 & 0.1184 & 5.0265 & 0.0687 & 0.0466 & 0.0251 & 1.8367
\end{tabular}




\begin{tabular}{cccccccccc}
\hline & LEV & STDR & LTDR & TANG & SIZE & GROWTH & ROA & TAX & LIQUID \\
\hline Maximum & 0.9912 & 0.9910 & 0.7246 & 0.9446 & 6.6957 & 4.7820 & 0.4700 & 0.9362 & 27.7273 \\
Minimum & 0.0273 & 0.0061 & 0.0000 & 0.0000 & 3.4467 & -0.8197 & -0.1711 & -0.0086 & 0.3372 \\
Std. dev. & 0.2523 & 0.2582 & 0.1491 & 0.2010 & 0.6077 & 0.7308 & 0.0720 & 0.0881 & 3.8034 \\
Skewness & 0.0247 & 0.4095 & 2.0958 & 1.4189 & 0.1961 & 3.3288 & 0.9742 & 5.0800 & 3.1305 \\
Kurtosis & 1.9445 & 2.1129 & 7.2329 & 4.5632 & 3.2772 & 18.4549 & 7.8565 & 40.0444 & 15.2596 \\
Number of obs. & 340 & 340 & 340 & 340 & 340 & 340 & 340 & 340 & 340 \\
\hline
\end{tabular}

Source: author's compilation using Eviews 8.0

The results of Table 4 highlight the mean of LEV, STDR, and LTDR of $49.1 \%$, $39.62 \%$, and $9.45 \%$ respectively. To the same extent, SOEs with state shareholding of less than $30 \%$ prefer equity and short-term debt financing. Long-term debt ratio for Group 3 enterprises, despite being at a low level, is higher than that for Group 1 and 2, both of which in turn reveal higher short-term debt ratios than Group 3. Additionally, maximum value of ROA reaches $47 \%$, whereas it's minimum value, $-17.11 \%$, found to be much lower than bank interest rates. Yet, the loss of Group 3 firms is less serious than those belonging to Group 2, as clearly reflected by Construction JSC No. 3, Imexco Trading JSC, Viky Plastic JSC, etc.

\subsubsection{Correlation matrix}

\section{Table 5}

Correlation matrix of variables for Group 1 firms

\begin{tabular}{|c|c|c|c|c|c|c|c|c|c|}
\hline & LEV & STDR & LTDR & TANG & SIZE & GROWTH & ROA & TAX & LIQUID \\
\hline LEV & 1.00000 & & & & & & & & \\
\hline STDR & 0.88894 & 1.00000 & & & & & & & \\
\hline LTDR & 0.15159 & -0.31799 & 1.00000 & & & & & & \\
\hline TANG & -0.45890 & -0.59390 & 0.33175 & 1.00000 & & & & & \\
\hline SIZE & 0.21107 & 0.11705 & 0.18430 & -0.00316 & 1.00000 & & & & \\
\hline GROWTH & 0.11045 & 0.09354 & 0.02676 & -0.07918 & -0.04604 & 1.00000 & & & \\
\hline ROA & -0.38570 & -0.32230 & -0.10284 & -0.18656 & 0.02317 & 0.03607 & 1.00000 & & \\
\hline TAX & -0.25754 & -0.20140 & -0.09847 & 0.03946 & -0.10801 & 0.05652 & 0.31093 & 1.00000 & \\
\hline LIQUID & -0.52952 & -0.57300 & 0.14048 & 0.07070 & -0.20975 & -0.06184 & 0.23157 & 0.13741 & 1.00000 \\
\hline
\end{tabular}

Source: author's compilation using Eviews 8.0 
The correlation coefficients displayed by Table 5 are less than 0.8 , implying that the variables applied to the models are usable. Leverage ratio and short-term debt ratio positively relate to size and growth with coefficients of 0.2110 and 0.117 but negatively relate to tangible assets, ROA, effective tax rate, and liquidity. Meanwhile, a positive correlation exists between the four variables (tangible assets, size, growth, and liquidity) and long-term debt ratio, whose negative correlation with ROA and effective tax rate is, in turn, found.

\section{Table 6}

Correlation matrix of variables for Group 2 firms

\begin{tabular}{cccccccccc}
\hline & LEV & STDR & LTDR & TANG & SIZE & GROWTH & ROA & TAX & LIQUID \\
\hline LEV & 1.00000 & & & & & & & & \\
STDR & 0.89298 & 1.00000 & & & & & & & \\
LTDR & 0.17226 & -0.28955 & 1.00000 & & & & & & \\
TANG & -0.42552 & -0.53170 & 0.25875 & 1.00000 & & & & & \\
SIZE & 0.45618 & 0.47433 & -0.06800 & -0.07640 & 1.00000 & & & & \\
GROWTH & -0.11162 & -0.08197 & -0.05796 & 0.07893 & -0.04560 & 1.00000 & & & \\
ROA & -0.35340 & -0.32759 & -0.03459 & 0.16993 & -0.01221 & 0.18060 & 1.00000 & & \\
TAX & -0.14367 & -0.11596 & -0.05174 & 0.03959 & -0.14051 & 0.12847 & 0.41136 & 1.00000 & \\
LIQUID & -0.59063 & -0.56916 & -0.01039 & 0.04027 & -0.42269 & 0.12121 & 0.09599 & -0.02528 & 1.00000 \\
\hline
\end{tabular}

Source: author's compilation using Eviews 8.0

Leverage ratio and short-term debt ratio are positively related to size with coefficients of 0.45618 and 0.47433 , while negatively relating to growth, tangible assets, ROA, effective tax rate, and liquidity. Among Group 2 enterprises, in addition, long-term debt ratio is only positively correlated with tangible assets.

\section{Table 7}

Correlation matrix of variables for Group 3 firms

\begin{tabular}{cccccccccc}
\hline & LEV & STDR & LTDR & TANG & SIZE & GROWTH & ROA & TAX & LIQUID \\
\hline LEV & 1.00000 & & & & & & & \\
STDR & 0.82923 & 1.00000 & & & & & & \\
LTDR & 0.25273 & -0.33075 & 1.00000 & & & & & \\
TANG & -0.11958 & -0.13590 & 0.03044 & 1.00000 & & & & & \\
& & & & & & & & & \\
\end{tabular}




\begin{tabular}{cccccccccc}
\hline & LEV & STDR & LTDR & TANG & SIZE & GROWTH & ROA & TAX & LIQUID \\
\hline SIZE & 0.17472 & 0.00703 & 0.28232 & -0.28046 & 1.00000 & & & & \\
GROWTH & 0.09103 & 0.10335 & -0.02229 & -0.06460 & -0.06457 & 1.00000 & & & \\
ROA & -0.37617 & -0.26743 & -0.17088 & -0.26415 & -0.02839 & -0.02806 & 1.00000 & & \\
TAX & -0.07367 & 0.00388 & -0.13030 & -0.06768 & -0.09567 & 0.04581 & 0.22274 & 1.00000 & \\
LIQUID & -0.49556 & -0.61656 & 0.23045 & -0.06866 & -0.11092 & 0.02549 & 0.24261 & -0.00589 & 1.00000 \\
\hline
\end{tabular}

Source: author's compilation using Eviews 8.0

Correlation coefficients among the variables in Table 7 are less than 0.8 ; thus, these variables can be accepted. Leverage ratio and short-term debt ratio positively relates to size and growth yet are negatively correlated with tangible assets, ROA, and effective tax rate. Long-term debt ratio is positively related to tangible assets, size, and liquidity.

\subsection{Results of model testing}

Three equations designed for the three groups of enterprises have been mentioned in the prior section of this study, comprising such dependent variables as LEV, STDR, and LTDR.

\subsubsection{Results of Pooled OLS estimation}

\section{Table 8}

Pooled OLS regression for Group 1 firms

\begin{tabular}{lllllll}
\hline & LEV & \multicolumn{3}{c}{ STDR } & LTDR & \\
\hline & Coefficient & Prob. & Coefficient & Prob. & Coefficient & Prob. \\
\hline C & $0.493893^{* * * *}$ & 0 & $0.727073^{* * *}$ & 0 & $-0.233162^{* * *}$ & 0.0009 \\
TANG & $-0.652419^{* * * *}$ & 0 & $-0.853379^{* * *}$ & 0 & $0.20098^{* * * *}$ & 0 \\
SIZE & $0.066651^{* * *}$ & 0.0007 & 0.015227 & 0.3652 & $0.051419^{* * *}$ & 0.0002 \\
GROWTH & $0.025687^{* *}$ & 0.0691 & 0.011529 & 0.3438 & 0.014154 & 0.1543 \\
ROA & $-1.313883^{* * *}$ & 0 & $-1.201482^{* * *}$ & 0 & -0.112312 & 0.2877 \\
TAX & $-0,107394$ & 0.1639 & -0.020322 & 0.76 & $-0.087078^{*}$ & 0.0912 \\
LIQUID & $-0.037998^{* * *}$ & 0 & $-0.048012^{* * *}$ & 0 & $0.009985^{* * *}$ & 0.0012 \\
R-squared & 0.619963 & & 0.73901 & & 0.192481 & \\
F-statistic & 67.4279 & & 117.0381 & & 9.852263 & \\
\hline
\end{tabular}

$*^{* * *}$, and ${ }^{* * *}$ denote significance levels of $10 \%, 5 \%$, and $1 \%$ respectively.

Source: author's compilation using Eviews 8.0 
Leverage ratio and short-term debt ratio, as can be seen, reveal negative correlations (statistically significant at $1 \%$ level) with tangible assets, liquidity, and ROA; particularly, a $1 \%$ increase in LEV and STDR would result in a decrease in tangible assets by $65.3 \%$ and $85.45 \%$ respectively. Therefore, the hypotheses H1, H4, and H6 can be accepted. These results are consistent with Deesomsak et al. (2004), Jong et al. (2008), Bas et al. (2009), and Liu et al. (2011), except for long-term debt ratio, which has a positive relation with tangible assets at the $1 \%$ significance level.

Firm size positively relates to leverage ratio and long-term debt ratio at $1 \%$ level, which is agreeable to hypothesis $\mathrm{H} 2$ and compatible with the findings from Deesomsak et al. (2004), Jong et al. (2008), Liu et al. (2011), and Okuda and Lai (2010).

Furthermore, correlations of effective tax rate with the three financial ratios are not highly significant. Group 1 enterprises reflect a high short-term debt ratio (see Table 1), yet correlation of their tax rate and long-term debt ratio is significant at $10 \%$ level. This implies that the variable of TAX has no impact on the capital structure of equitized SOEs with state shareholding of $51 \%$ or more.

\section{Table 9}

Pooled OLS regression for Group 2 firms

\begin{tabular}{ccccccc}
\hline & \multicolumn{2}{c}{ LEV } & \multicolumn{2}{c}{ STDR } & \multicolumn{2}{c}{ LTDR } \\
\hline & Coefficient & Prob. & Coefficient & Prob. & Coefficient & Prob. \\
\hline C & 0.119028 & 0.3432 & -0.012014 & 0.3186 & 0.131035 & 0.1491 \\
TANG & $-0.501076^{* * *}$ & 0 & $-0.683055^{* * *}$ & 0 & $0.181958^{* * *}$ & 0.0001 \\
SIZE & $0.12651^{* * *}$ & 0 & $0.14574^{* * *}$ & 0 & -0.019227 & 0.3005 \\
GROWTH & 0.010781 & 0.5113 & 0.022133 & 0.1508 & -0.011349 & 0.3386 \\
ROA & $-0.553131^{* * *}$ & 0 & $-0.504241^{* * *}$ & 0 & -0.048898 & 0.5227 \\
TAX & 0.021147 & 0.827 & 0.024021 & 0.791 & -0.045153 & 0.5183 \\
LIQUID & $-0.022155^{* * *}$ & 0 & $-0.021198^{* * *}$ & 0 & -0.000957 & 0.5613 \\
R-squared & 0.611208 & & 0.677764 & & 0.082956 & \\
F-statistic & 58.4285 & & 78.17308 & & 3.62118 & \\
\hline
\end{tabular}

$*^{* * *}$, and ${ }^{* * *}$ denote significance levels of $10 \%, 5 \%$, and $1 \%$ respectively.

Source: author's compilation using Eviews 8.0

At $1 \%$ level leverage ratio and short-term debt ratio are shown to negatively relate to tangible assets, ROA, and liquidity, complying with hypotheses H1, H4, and H6 and 
Deesomsak et al. (2004), Jong et al. (2008), Ozkan (2002), and Liu et al. (2011). Correlations of long-term debt ratio are not statistically significant, except for its positive correlation with tangible assets at 1\% level, consistent with Okuda and Lai (2010).

Size, at $1 \%$ level, are positively related to leverage ratio and short-term debt ratio (hypothesis H2; Jong et al., 2008; and Liu et al., 2011), whereas its correlation with longterm debt ratio is not statistically significant.

Effective tax rate and growth have no significant correlation with the financial ratios as for Group 2, which reflects a low leverage ratio ( $48.66 \%$ on average), as compared to the others. These equitized SOEs show little interest in tax shield benefits during the use of financial leverage since debt financing sources are mainly the short-term ones.

\section{Table 10}

Pooled OLS regression for Group 3 firms

\begin{tabular}{ccccccc}
\hline & \multicolumn{2}{c}{ LEV } & \multicolumn{2}{c}{ STDR } & \multicolumn{2}{c}{ LTDR } \\
\hline Coefficient & Prob. & Coefficient & Prob. & Coefficient & Prob. \\
\hline TANG & $-0.562532^{* * *}$ & 0 & $0.906943^{* * *}$ & 0 & $-0.342937^{* * *}$ & 0 \\
SIZE & $0.0259592^{* * *}$ & 0 & $-0.332568^{* * *}$ & 0 & $0.065052^{*}$ & 0.1000 \\
GROWTH & $0.029042^{*}$ & 0.0547 & 0.031002 & 0.0304 & -0.001469 & 0.8834 \\
ROA & $-1.123149^{* * *}$ & 0 & $-0.690346^{* * *}$ & 0 & $-0.42901^{* * *}$ & 0.0001 \\
TAX & -0.048749 & 0.7039 & 0.02654 & 0.2827 & -0.074803 & 0.3806 \\
LIQUID & $-0.028375^{* * *}$ & 0 & $-0.041033^{* * *}$ & 0 & $0.012682^{* * *}$ & 0 \\
R-squared & 0.377628 & & 0.467473 & & 0.212334 & \\
F-statistic & 33.67501 & & 48.7201 & & 14.96131 & \\
(Prob) & $(0.0000)$ & & $(0.0000)$ & & $(0.0000)$ & \\
\hline
\end{tabular}

${ }^{*},{ }^{* *}$, and ${ }^{* * *}$ denote significance levels of $10 \%, 5 \%$, and $1 \%$ respectively.

Source: author's compilation using Eviews 8.0

The regression results as shown by Table 10 negative correlations exists among leverage ratio, short-term debt ratio, and other factors, namely tangible assets, ROA, and liquidity, consistent with hypotheses H1, H4, H6, and similar to Myers and Majluf (1984), Deesomsak et al. (2004), Jong et al. (2008), and Liu et al. (2011). 
Long-term debt ratio is positively related to tangible assets, size, and liquidity, whereas its correlation with ROA is negative, which is accordingly different from that for Group 1 and Group 2 firms.

Moreover, correlations of effective tax rate and growth with the financial ratios are not significant for Group 3 firms. A positive correlation is held between size and longterm debt ratio (hypothesis H2; Liu et al., 2011; Okuda \& Lai, 2010), but the size negatively relates to short-term debt ratio at $1 \%$ level. The level of state ownership, hence, is low for Group 3, and the bigger the firm size, the higher the financial leverage (long-term debt).

\subsubsection{Tests for potential autocorrelation and heteroscedasticity}

\section{Autocorrelation testing}

Autocorrelation refers to the correlation of $\mathrm{u}_{\mathrm{i}}$, thus making OLS estimation inaccurate. For this reason the study continues to use Durbin-Watson test, based on results obtained from Pooled OLS regression for the three models.

\section{Table 11}

Results of autocorrelation testing

\begin{tabular}{cccc}
\hline \multirow{2}{*}{ Dependent variable } & \multicolumn{3}{c}{ Durbin-Watson } \\
\cline { 2 - 4 } & Group 1 & Group 2 & Group 3 \\
\hline LEV & 0.927737 & 0.919241 & 0.753334 \\
STDR & 1.188293 & 0.876427 & 1.013132 \\
LTDR & 0.777873 & 0.848219 & 0.872391 \\
\hline
\end{tabular}

Source: author's compilation using Eviews 8.0

Apart from the case of STDR for Groups 1 and 3, the values of Durbin-Watson statistic are all less than 1 , which indicates the occurrence of autocorrelation for the three models.

\section{Heteroscedasticity testing}

White and Breusch-Pagan tests are used to check for heteroscedasticity. The null hypothesis is that the variance of random error is constant.

$\mathrm{H}_{0}$ is accepted and no heteroscedasticity occurs if $\mathrm{p}$-value $>0.05$.

$\mathrm{H}_{0}$ is rejected and heteroscedasticity occurs if $\mathrm{p}$-value $<0.05$. 


\section{Table 12}

Results of heteroscedasticity testing

\begin{tabular}{ccccccc}
\hline & \multicolumn{5}{c}{ Breusch-Pagan } \\
\cline { 2 - 6 } & Group 1 & \multicolumn{2}{c}{ Group 2 } & \multicolumn{2}{c}{ Group 3 } \\
\cline { 2 - 6 } & Obs*R-squared & Prob & Obs*R-squared & Prob & Obs*R-squared & Prob \\
\hline LEV & 176.5288 & 0 & 114.7298 & 0 & 299.0376 & 0 \\
STDR & 88.1339 & 0 & 154.328 & 0 & 192.9789 & 0 \\
LTDR & 273.0679 & 0 & 91.5806 & 0 & 159.2814 & 0 \\
\hline
\end{tabular}

Source: author's compilation using Eviews 8.0

Since p-values are smaller than 0.05 (Table 12 ), $\mathrm{H}_{0}$ is rejected, which implies heteroscedasticity for the three models. Pooled OLS estimation is thus no longer suitable, and the study proceeds to apply FEM and REM.

4.3.3. Hausman test for fixed effects model (FEM) and random effects model (REM)

To overcome the problem of autocorrelation and heteroscedasticity, the study applies Hausman test for the selection between FEM and REM, together with the following hypotheses:

$\mathrm{H}_{0}$ : FEM and REM estimates are significantly similar.

$\mathrm{H}_{1}$ : FEM is more suitable than REM.

\section{Table 13}

Results of Hausman testing

\begin{tabular}{ccccccc}
\hline & \multicolumn{2}{c}{ Group 1 } & \multicolumn{2}{c}{ Group 2 } & \multicolumn{2}{c}{ Group 3 } \\
\cline { 2 - 7 } & Chi $^{2}$ & Prob & Chi $^{2}$ & Prob & Chi $^{2}$ & Prob \\
\hline LEV & 60.648106 & 0 & 39.816212 & 0 & 69.397995 & 0 \\
STDR & 106.936853 & 0 & 40.977935 & 0 & 69.637622 & 0 \\
LTDR & 53.907026 & 0.0286 & 13.632837 & 0.034 & 61.98211 & 0.041 \\
\hline
\end{tabular}

Source: author's compilation using Eviews 8.0

The results of Hausman test indicate that p-values are less than 0.05 , so the null hypothesis can be rejected. The fact that $\mathrm{H}_{1}$ is accepted implies that using FEM produces more positive results. 
4.3.4. Estimation with fixed effects regression

After the Hausman test, FEM-based regression model is used with results for the three models as is shown in Table 14.

\section{Table 14}

Regression results based on FEM for Group 1 firms

\begin{tabular}{cccc}
\hline & LEV & STDR & LTDR \\
\hline C & Coefficient & Coefficient & Coefficient \\
\hline TANG & $-0.407308^{* * *}$ & -0.125207 & $-0.073158^{* * *}$ \\
SIZE & $-0.107165^{* * *}$ & $-0.193211^{* * * *}$ & $0.023372^{* * *}$ \\
GROWTH & $0.207119^{* * *}$ & $0.140551^{* * *}$ & $0.027367^{* * *}$ \\
ROA & $0.005411^{* * *}$ & $0.01145^{* * *}$ & -0.000362 \\
TAX & $-0.55756^{* * *}$ & $-0.5543^{* * *}$ & 0.002403 \\
LIQUID & -0.043328 & -0.047818 & 0.00467 \\
R-squared & $-0.014115^{* * *}$ & $-0.017256^{* * *}$ & 0.000418 \\
F-statistic & 0.993392 & 0.98904 & 0.905924 \\
(Prob) & 531.567 & 319.0687 & 34.04774 \\
Durbin-Watson & $(0.0000)$ & $(0.0000)$ & $(0.0000)$ \\
& 1.873888 & 2.016869 & 1.898335 \\
\hline
\end{tabular}

${ }^{*}, * *$, and ${ }^{* * *}$ denote significance levels of $10 \%, 5 \%$, and $1 \%$ respectively.

Source: author's compilation using Eviews 8.0

Leverage ratio and short-term debt ratio are shown to positively relate to size and growth but negatively relate to tangible assets, liquidity, ROA, and effective tax rate. This also demonstrates that the factor of tax rate has no impact on the capital structure of equitized SOEs with state shareholding of $51 \%$ or more, whereas effects of the size and tangible assets are particularly significant on leverage decisions of Group 1 firms.

Similarity is shared in findings from FEM and Pooled OLS estimates (Jong et al., 2008; Liu et al., 2011; Nguyen \& Ramachandran, 2006). The FEM estimation produces more significant results for long-term debt ratio, and adjusted $\mathrm{R}^{2}$ indicates a higher 
proportion of variance in the financial ratios explained (99.33\%, 98.9\%, and 90.6\%). Durbin-Watson statistic reports no more autocorrelation in the models.

\section{Table 15}

Regression results based on FEM for Group 2 firms

\begin{tabular}{lccc}
\hline & LEV & STDR & LTDR \\
\hline Coefficient & Coefficient & Coefficient \\
TANG & $-0.581999^{* * *}$ & $-0.650492^{* * *}$ & $0.073657^{* * *}$ \\
SIZE & $-0.215174^{* * *}$ & $-0.193233^{* * *}$ & -0.008766 \\
GROWTH & $0.251038^{* * *}$ & $0.251893^{* * *}$ & -0.003508 \\
ROA & $0.011256^{* * *}$ & 0.009251 & 0.000217 \\
TAX & $-0.488119^{* * *}$ & $-0.318531^{* * *}$ & $-0.032267^{*}$ \\
LIQUID & $0.181937^{* * *}$ & $0.169167^{* * *}$ & $0.007185^{*}$ \\
R-squared & $-0.00875^{* * *}$ & $-0.011461^{* * *}$ & $0.001631^{* * *}$ \\
F-statistic & 0.989981 & 0.992455 & 0.95144 \\
(Prob) & 344.8608 & 459.0842 & 68.38434 \\
Durbin-Watson & $(0.0000)$ & $(0.0000)$ & $(0.0000)$ \\
\hline
\end{tabular}

${ }^{*}, * *$, and ${ }^{* * *}$ denote significance levels of $10 \%, 5 \%$, and $1 \%$ respectively.

Source: author's compilation using Eviews 8.0

For Table 15, leverage ratio and short-term debt ratio are positively correlated with size, growth, and effective tax rate but their negative correlations are held with tangible assets, liquidity, and ROA at $1 \%$ level, which offers better results compared to those achieved from the Pooled OLS estimation. For long-term debt ratio regression results are not highly significant (Group 2 firms prefer short-term one), except for the results for liquidity. Adjusted $\mathrm{R}^{2}$ indicates that a higher variance in the financial ratios is explained $(98.99 \%, 99.25 \%$, and $95.14 \%)$ and no autocorrelation is found. 


\section{Table 16}

Regression results based on FEM for Group 3 firms

\begin{tabular}{lccc}
\hline & LEV & STDR & LTDR \\
\hline C & Coefficient & Coefficient & Coefficient \\
TANG & $-1.626031^{* * * *}$ & $-0.779721^{* * * *}$ & $-0.177446^{* * *}$ \\
SIZE & $-0.04197^{* * *}$ & $-0.131764^{* * *}$ & $0.038579^{* * *}$ \\
GROWTH & $0.433189^{* * *}$ & $0.2484^{* * *}$ & $0.05318^{* * *}$ \\
ROA & $0.010278^{* * *}$ & $0.014519^{* * *}$ & -0.001333 \\
TAX & $-0.24116^{* * *}$ & -0.0128 & $-0.154277^{* * *}$ \\
LIQUID & $-0.215484^{* * *}$ & $-0.125371^{* *}$ & $-0.076653^{* *}$ \\
R-squared & $-0.012942^{* * *}$ & $-0.015495^{* * *}$ & $0.002683^{* * *}$ \\
F-statistic & 0.99052 & 0.984507 & 0.882432 \\
(Prob) & 380.7088 & 231.5415 & 27.34971 \\
Durbin-Watson & $(0.0000)$ & $(0.0000)$ & $(0.0000)$ \\
& 1.832683 & 1.930951 & 1.827668 \\
\hline
\end{tabular}

${ }^{*},{ }^{* *}$, and ${ }^{* * *}$ denote significance levels of $10 \%, 5 \%$, and $1 \%$ respectively.

Source: author's compilation

The results suggested in Table 16 verify that leverage ratio and short-term debt ratio positively relate to size and growth at $1 \%$ level. Long-term debt ratio positively relates to tangible assets, size, and liquidity, yet negatively relates to ROA and effective tax rate. The regression results for Group 3 are more highly significant than Pooled OLS findings. Determinants of the long-term debt ratio other than growth are significant at $1 \%$ level. Similarly, high values of adjusted $\mathrm{R}^{2}$ signify better explanation power for the variance in the ratios $(99.0 \%, 98.45 \%, 88.24 \%)$, and among the three models there exists no autocorrelation.

\section{Result discussion}

The FEM-based regression results indicate several differences in the level of impact on capital structure of Groups 1, 2, and 3; consistency and inconsistency can be discussed as follows: 
For SOEs leverage decisions are greatly affected by size, tangible assets, ROA, and liquidity (Jong et al., 2008). Still, long-term debt ratio of Groups 1 and 2 firms is less influenced by these factors as those with a high level of state ownership are prioritized in debt financing.

Tangible assets and ROA are negatively correlated with leverage ratio and short-term debt ratio among the three groups (the results agree and disagree with $\mathrm{H} 4$ and $\mathrm{H} 1$ respectively), yet positively relate to long-term debt ratio of Groups 1 and 3 (Myers \& Majluf, 1984; Jong et al., 2008; Bas et al., 2009; Ozkan, 2002; Liu et al., 2011). Accordingly, among equitized SOEs the larger the tangible assets, the lower the leverage or the higher the level of state ownership, and ROA is found not to influence the longterm financial leverage.

Size is positively related to leverage ratio and short-term debt ratio among the three groups of enterprises (Myers, 1984; Deesomsak et al., 2004; Okuda \& Lai, 2010). Likewise, the results suggest certain differences in the impact of size on leverage, which becomes more profound when a higher level of state ownership is reflected within equitized SOEs.

The results of growth in correlation with the three financial ratios are highly statistically significant.

Correlations of effective tax rate are not statistically significant with the financial ratios for the case of Group 1, but for Groups 2 and 3 they are significant, implying that equitized SOEs show little interest in tax shield benefits; the key financing sources are short-term debt, whereas growth rate exerts no impact on their capital structure.

Regarding Groups 2 and 3, correlations of liquidity with long-term debt ratio are significant at $1 \%$ level, and its correlations with leverage ratio and short-term debt ratio are negative and significant at $1 \%$ level for the three groups. Since short-term debt is mainly owed by equitized SOEs, a high liquidity level would support them with repayment capacity (Deesomsak et al, 2004; Jong et al., 2008).

\section{Conclusion and implications}

\subsection{Conclusion}

Even though the factors affecting capital structure are much researched in various countries, this study focuses on its determinants for the case of Vietnam's equitized 
SOEs. Its findings have indicated that such factors as tangible assets, ROA, and liquidity are all negatively related to leverage ratio and short-term debt ratio at the $1 \%$ significance level for the three surveyed groups, consistent with Myers and Majluf (1984) and Liu et al. (2011).

Contrarily, firm size and growth are positively related to leverage ratio and shortterm debt ratio at $1 \%$ level for the three groups, as similarly found by Myers and Majluf (1984), Deesomsak et al. (2004), and Okuda and Lai (2010). Correlations of effective tax rate with the financial ratios, albeit insignificant for Group 1, are statistically significant for Group 2 and 3 firms.

\subsection{Implications}

The current state of the capital structure of equitized SOEs show that primary financing sources among the firms are equity (average equity/total assets ratio of $95.52 \%$ and $89.43 \%$ for Phu Tho Plastic JSC and Ben Thanh Water Supply JSC respectively) and short-term debt (average short-term debt/total assets ratio of $87.1 \%$ and $88.9 \%$ for Khanh Hoi Pharmaceutical \& Medical Service JSC and Medical Import Export JSC respectively). Thus, it is imperative for these firms' financing sources to be restructured to boost their returns.

Conversion of types of debt financing

Among the surveyed equitized SOEs a high proportion of short-term debt is readily recognizable; hence, one point to be considered by financial managers is to estimate a proper timeline for conversion into long-term debt (e.g., long-term loans from banks or bond issuance in order to utilize the merits of low interest rates in case of high inflation rates or the benefits of the tax shield offered by debt financing).

By transferring loans to investors in the form of long-term revenue bonds, these firms manage to convert short-term debt sources into long-term ones applied to bondholders and the pitfalls of difference in debt maturities can also be avoided. Furthermore, they shall issue bonds guaranteed by collateralized debt obligation (CDO). The legal framework for corporate bond issuance has been governed by Decree No.90/2011/ND$\mathrm{CP}$, whereby the rules are under loosened legal control, which fosters firms in their increasing financing sources and reforming loan terms.

Agents and efficiency of performance 
Realities show a variety of problems facing equitized SOEs to include losses stemming from poor business performance and investment, financial impropriety and loosely managed funds, and more importantly, the agent ownership in subsidiaries or affiliated companies with insufficient rights.

Nevertheless, Circular No. 21/2014/TT-BTC clearly discussed the duties of agents, through whom firms should implement their monitoring mechanisms to tighten financial management, minimize violations, and improve efficiency in state financing for this kind of firms.

\section{Level of state ownership in equitized SOEs}

The results on firms' state ownership demonstrate that those with state shareholding of $51 \%$ or more account for $30.9 \%$ of the sample. A high proportion of state investment in these firms allows for ownership of fixed assets (i.e. land in prime locations offering cheap rental prices), large intangible assets, and other preferences for business operations as well as credit support.

Thus, to lower the percentage of state shareholding in equitized SOEs, there is a need for divestment under par value in businesses with losses, which should be realized after setting aside provisions for losses of financial investments as regulated. The transfer of investments in unlisted JSCs having investments greatly valued at par value, divestment methods, and selection of intermediary financial institutions are also to be considered.

On top of that, State Capital and Investment Corporation (SCIC) should consider acquiring investments outside core business lines or in insurance and banking domains engaged by state-run economic groups, corporations, and 100\% SOEs.

\section{Human resources in equitized SOEs}

There is a requirement that high quality human resources should be exploited to facilitate smooth operations of equitized SOEs. Well-trained management staff would serve to drive firms along market economy practices and monitor effective performance to enable them to actively use different financing sources. Clear, transparent, and ethical recruitment and assignment processes are crucial to attracting talented staff.

Currently, the adequate level of state presence in economic groups and corporation during equitization which may optimize their efficiency and harmonize social and economic objective has yet to be examined, thus demanding further research 


\section{References}

Bas, T., Gulnur, M., \& Kate, P. (2009). Determinants of capital structure in developing countries (Working Paper). London, UK: Cass Business School.

Chen, J. J. (2004). Determinants of capital structure of Chinese-listed companies. Journal of Business Research, 57(12), 1341-1351.

Deesomsak, R., Paudyal, K., \& Pescetto, G. (2004). The determinants of capital structure: Evidence from the Asia pacific region. Journal of Multinational Financial Management, 14(4-5), 387-405.

Dewenter, K., \& Pettway, R. H. (2001). Visibility versus complexity in business groups: Evidence from Japanese Keiretsu. Journal of Business, 74(1), 79-100.

Firth, M., Linb, C., Liua, P., \& Wonga, S. M. L. (2009). Inside the black box: Bank credit allocation in China's private sector. Journal of Banking and Finance, 33(6), 1144-1155.

Jensen, M. C., \& Meckling, W. H. (1976). Theory of the firm: Managerial behavior, agency costs, and ownership structure. Journal of Financial Economics, 3(4), 305-360.

Jong, A. D., Kabir, R., \& Nguyen, T. T. (2008). Capital structure around the world: The roles of firmand country-specific determinants. Journal of Banking and Finance, 32(9), 1954-1969.

Li, K., Yue, H., \& Zhao, L. K. (2009). Ownership, institutions, and capital structure: Evidence from China. Journal of Comparative Economics, 37(3), 471-490.

Liu, Q., Tian, G., \& Wang, X. (2011). The effect of ownership structure on leverage decision: New evidence from Chinese listed firms. Journal of the Asia Pacific Economy, 16(2), 254-276.

MacKie-Mason, J. K. (1990). Do taxes affect corporate financing decisions? Journal of Finance, 45 , 1471-1493.

Modigliani, F., \& Miller, M. H. (1958). The cost of capital, corporate finance, and the theory of investment. The American Economic Review, 48(3), 261-297.

Myers, S. C., \& Majluf, N. (1984). Corporate financing and investment decisions when firms have information that investors do not have. Journal of Financial Economics, 13(2), 187-221.

Nadeem, A. S., \& Wang, Z. (2011). Determinants of capital structure: An empirical study of firms in manufacturing industry of Pakistan. Managerial Finance, 37(2), 117-133.

Nguyen, T. D. K., \& Ramachandran, N. (2006). Capital structure in small and medium-sized enterprises: The case of Vietnam. ASEAN Economic Bulletin, 23(2), 192-211.

Okuda, H., \& Lai, T. P. N. (2010). The determinants of the fundraising structure of listed companies in Vietnam: Estimation of the effects of government ownership (Global COE Hi-Stat Discussion Paper Series gd09-110). Tokyo, Japan: Institute of Economic Research, Hitotsubashi University.

Ozkan, A. (2002). An empirical analysis of corporate debt maturity structure. European Financial Management, 6(2), 197-212. 
Rajan, R. G., \& Zingales, L. (1995). What do we know about capital structure? Some evidence from international data. The Journal of Finance, 50(5), 1421-1460.

Scott, J. H. Jr. (1977). Bankruptcy, secured debt, and optimal capital structure. The Journal of Finance, 32(1), 1-19.

Sheikh, N. A., \& Wang, Z. (2011). Determinants of capital structure: An empirical study of firms in manufacturing industry of Pakistan. Managerial Finance, 37(2), 117-133.

Tran, N. T. (2007). Modern corporate finance (in Vietnamese). Hanoi, Vietnam: Statistical Publishing House.

Vietnamese Government. (2006). Decision No. 15/2006/QD-BTC on issuing business accounting system. Retrieved from http://thuvienphapluat.vn/archive/Decision-No-15-2006-QD-BTC-onissuing-enterprise-accounting-system-vb72834.aspx

Vietnamese Government. (2011). Decree No. 90/2011/ND-CP on issuance of corporate bonds. Retrieved from http://lawfirm.vn/?a=doc\&id=2422

Vietnamese Government. (2012). Decision No. 929/QD-TTg on approval of scheme 'Restructuring of state-owned enterprises, 'focusing on economic groups and state-owned corporations period 2011-2015. Retrieved from http://thuvienphapluat.vn/archive/Decision-No-929-QD-TTg-onapproval-of-scheme-restructuring-of-state-owned-ente-vb178251.aspx

Vietnamese Government. (2013). Circular No. 220/2013/TT-BTC guiding implementation of a number of articles of the Government's Decree No. 71/2013/ND-CP dated July 11, 2013, on state capital investment in enterprises and financial management over enterprises in which state holds 100\% of charter capital. Retrieved from http://thuvienphapluat.vn/archive/Circular-No-2202013-TT-BTC-guiding-Decree-No-71-2013-ND-CP-state-capital-investment-in-enterprisesvb220694.aspx

Vietnamese Government. (2014). Circular No. 21/2014/TT-BTC promulgating the regulation on activities of authorized representatives for state capital invested in enterprises. Retrieved from http://thuvienphapluat.vn/archive/Circular-No-21-2014-TT-BTC-activities-of-authorizedrepresentatives-for-state-capital-invested-in-enterprises-vb231246.aspx

Wald, J. K. (1999). How firm characteristic affect capital structure: An international comparison. Journal of Financial Research, 22(2), 161-187. 